\title{
Morphological abnormality in a Longnose Stingray Hypanus guttatus (Bloch \& Schneider, 1801) (Myliobatiformes: Dasyatidae)
}

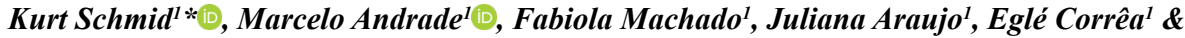 \\ Tommaso Giarrizzo ${ }^{1}$ \\ ${ }^{1}$ Universidade Federal do Pará, Núcleo de Ecologia Aquática e Pesca da Amazônia, Av. Perimetral, 2651, \\ Terra Firme, 66075-110, Belém, PA, Brasil \\ *Corresponding author: KurtSchmid, e-mail:kurtschmid_@hotmail.com
}

SCHMID, K., ANDRADE. M., MACHADO, F., ARAUJO, J. CORRÊA, E., GIARRIZZO, T. Morphological abnormality in a Longnose Stingray Hypanus guttatus (Bloch \& Schneider, 1801) (Myliobatiformes: Dasyatidae). Biota Neotropica. 19(4): e20190792. http://dx.doi.org/10.1590/1676-0611-BN-2019-0792

\begin{abstract}
A Longnose stingray Hypanus guttatus (Bloch \& Schneider, 1801) embryo with a major asymmetrical morphological abnormality to its pectoral fin was obtained from commercial shrimp fisher's bycatch, off the coast of the Amazon River Mouth in northern Brazil. The specimen and the deformity, which would presumably have impeded its long-term survival, are described and documented in detail. We herein provide the first report of an abnormal individual of this species for the Brazilian coast.
\end{abstract}

Keywords: Fish, Elasmobranchs, Atlantic, Teratology, Deformity.

\section{Anormalidade morfológica em uma Arraia-bicuda Hypanus guttatus (Bloch \& Schneider, 1801) (Myliobatiformes: Dasyatidae)}

Resumo: Um embrião de Arraia-bicuda Hypanus guttatus (Bloch \& Schneider, 1801) com uma anomalia morfológica assimétrica grave na nadadeira peitoral foi obtido como captura-acidental de um barco de pesca de camarão da costa da foz do rio Amazonas, no norte do Brasil. O indivíduo e sua deformação, que provavelmente teria impedido sua sobrevivência ao longo prazo, são descritos e documentados em detalhe. Apresentamos com esse estudo o primeiro registro de um indivíduo anormal dessa espécie para a costa do Brasil.

Palavras-chave: Peixes, Elasmobrânquios, Atlântico, Teratologia, Deformação.

\section{Introduction}

The longnose stingray Hypanus guttatus (Bloch \& Schneider, 1801), Dasyatidae, is widespread throughout the tropical waters of the western Atlantic Ocean from the southern Gulf of Mexico to the southern coast of São Paulo in Brazil. This aplacental viviparous stingray inhabits shallow water areas to at least $36 \mathrm{~m}$ in depth, has been found primarily on sandy bottoms and feeds predominantly on mobile invertebrates (Anderson et al. 2015, Froese \& Pauly 2018). Hypanus guttatus is a commercially important species in certain regions, such as the Caribbean coast of Colombia, Venezuela and Northeastern Brazil, where it is primarily targeted by artisanal fisheries (Cervigón \& Alcalá 1999, Ramírez-Hernandez et al. 2011).

There have been several reports of morphological abnormality in specimens of the genera Dasyatis and Hypanus, from both the Atlantic and Pacific Oceans. The vast majority of the deformities have been found in the head, rostrum and pectoral fin (Gomes et al. 1991, Lamilla et al. 1995, Escobar-Sanchéz et al. 2009, Blanco-Parra \& Niño-Torres 2011), while there have been fewer reports of abnormality in other parts, such as gonads, internal organs, tail and teeth (Ribeiro-Prado et al. 2008, Ramírez-Hernandez et al. 2011). Here we describe in detail the morphological abnormalities of a $H$. guttatus embryo, captured off the Brazilian Amazon Coast, as the first record for this taxon from this region.

\section{Material and Methods}

The $H$. guttatus embryo with its yolk sac still present was collected approximately 200-km off the coast of the Amazon River mouth $\left(1^{\circ} 23^{\prime} 54.4\right.$ " N 48 $\left.07^{\prime} 37.2^{\prime \prime} \mathrm{W}\right)$ in February 2017, as bycatch during a bottom trawl for the southern brown shrimp Farfantepenaeus subtilis (Pérez-Farfante, 1967), in approximately $43 \mathrm{~m}$ depth (Figure 1). The embryo was identified based on Carpenter and Niem (1999), measured, weighed, fixed in $10 \%$ formalin, and deposited in the fish collection of the Grupo de Ecologia Aquática (GEA 3677). No other individuals (e.g. more embryos or a pregnant female) of $H$. guttatus were captured during this trawl. A morphological description of the embryo and measurements were conducted based on Gomes et al. (2000) (Table 1). Additionally, measurements were taken for: (1) preorbital length (snout tip along sagittal axis of body to the eye level), (2) snout to aperture 
end of the pectoral fin, a linear measurement from the snout tip through the sagittal axis to the aperture end of the pectoral fin level, and (3) anterior margin of cranium to aperture end of the pectoral fin, measured as in the previous item (Figure 2). The internal anatomy was visualized by radiography performed on a Phillips Aquilla Plus 300 device at 45 $\mathrm{kVolts}$ and $50 \mathrm{~mA}$ for $2.5 \mathrm{mAs}$ at the Universidade Federal Rural da Amazônia (UFRA).

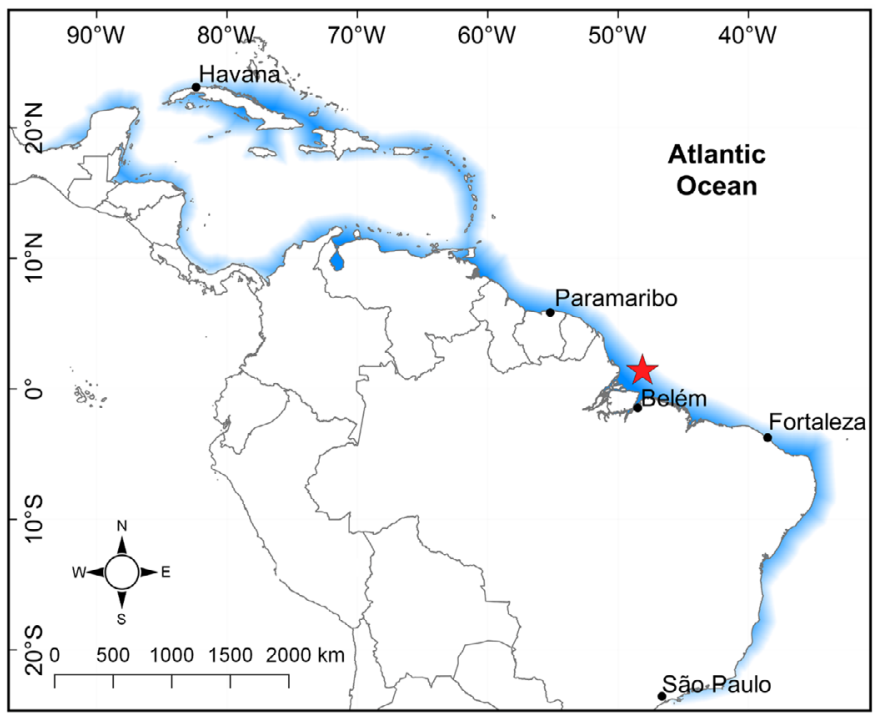

Figure 1. Distribution of Hypanus guttatus (Bloch \& Schneider, 1801) (blue shading) according to Rosa and Furtado (2004), and the collection site (red star) at $200 \mathrm{~km}$ offshore Amazon River mouth, Brazil.

\section{Results}

The H. guttatus embryo had a morphological abnormality that formed an aperture from the anterior margin of the snout around the left margin of the disc to the fourth gill slit (Figure 2, Table 1). In addition to the clearly separated pectoral fin, the left branchial arches (on the deformed side) appeared to be more widely interspaced, albeit more regularly formed than on the right side (Figure 3). The pectoral fins presented convex anterior margins and slightly straightened posterior margins. The embryo's disc length was slightly shorter than its width and its eye diameter was smaller than the spiracle length. Although the $\mathrm{x}$-ray imaging (Figure 3) does not provide full evidence, the cranium and jaw musculature do not seem to present an evident abnormality. Moreover, other morphological features of the specimen are consistent with other accounts of the species, such as that by Bigelow \& Schroeder (1953) and Last et al. (2016).

\section{Discussion}

The cause of the pectoral fin separation found in the H. guttatus embryo remains unknown. Pectoral fin separation from the head has been described as a common feature in the early stages of batoid embryonic development, with possible causes including parasitic infection, natural developmental mutation as well as injury- and environmental stressorinduced (e.g. long-term exposure to chemical pollution) teratogenic responses (Mancini et al. 2006, Ramírez-Hernandez et al. 2011).
Table 1. Measurements of the Hypanus guttatus (Bloch \& Schneider, 1801) specimen (GEA 3677).

\begin{tabular}{lc}
\hline Measurement & (mm) \\
\hline Disc width & 95.9 \\
Disc length & 96.6 \\
Total length & 271.6 \\
Disc length to axil of pectoral fin & 44.4 \\
Preoral length & 27.2 \\
Preorbital length & 27.6 \\
Snout to cloaca & 89.9 \\
Snout to aperture end & 50.4 \\
Cloaca to sting base & 39.8 \\
Tail length & 199.2 \\
Tail height & 4.9 \\
Height of dorsal finfold & 0.5 \\
Eye diameter & 7.2 \\
Spiracle length & 8.8 \\
Cranial interorbital & 15.6 \\
Cranium anterior margin to aperture end & 30.9 \\
Interspiracular & 24.7 \\
Internarial & 6.4 \\
Mouth width & 5.4 \\
Distance between first pair of gill slits & 12.3 \\
Distance between first and fifth gill slits & 9.0 \\
Pelvic fin anterior margin & 4.1 \\
Pelvic fin posterior margin & 10.2 \\
\hline &
\end{tabular}

Morphological abnormalities of the fins could directly impact a fish's mobility, affecting both its ability to forage and/or avoid predators, thereby reducing its likelihood of survival (Mancini et al. 2006). Although the morphological abnormality found in the embryo from this study could have presumably impeded its long-term survival, a similar malformation was recorded in a mature male $H$. guttatus captured in the Colombian Caribbean (Ramírez-Hernandez et al. 2011). This mature male had a disc width if $520 \mathrm{~mm}$; however, the abnormality was symmetrical and divided the snout equally, which presumably had a reduced impact on the swimming kinematics of the individual, thus allowing it to reach adult size. The abnormality of the H. guttatus embryo was asymmetrical and would presumably have had a negative impact on the swimming capacity of the individual, post-embryonically. That being said, Ribeiro-Prado et al. (2008) reported a female Pteroplatytrygon violacea (Bonaparte, 1832) (Dasyatidae) specimen which reached maturity, carrying an embryo, regardless of exhibiting very similar asymmetrical anomaly-a one-sided deeply unfused pectoral fin.

Scientific records of abnormalities for elasmobranchs are generally much rarer than for teleost fishes. The present report is only the second for an abnormal $H$. guttatus specimen, and the first from the Brazilian coast and for an embryo of this species thus providing an important biogeographic insight on abnormalities for this genus and species, given that existing and future reports contribute to the detection of 

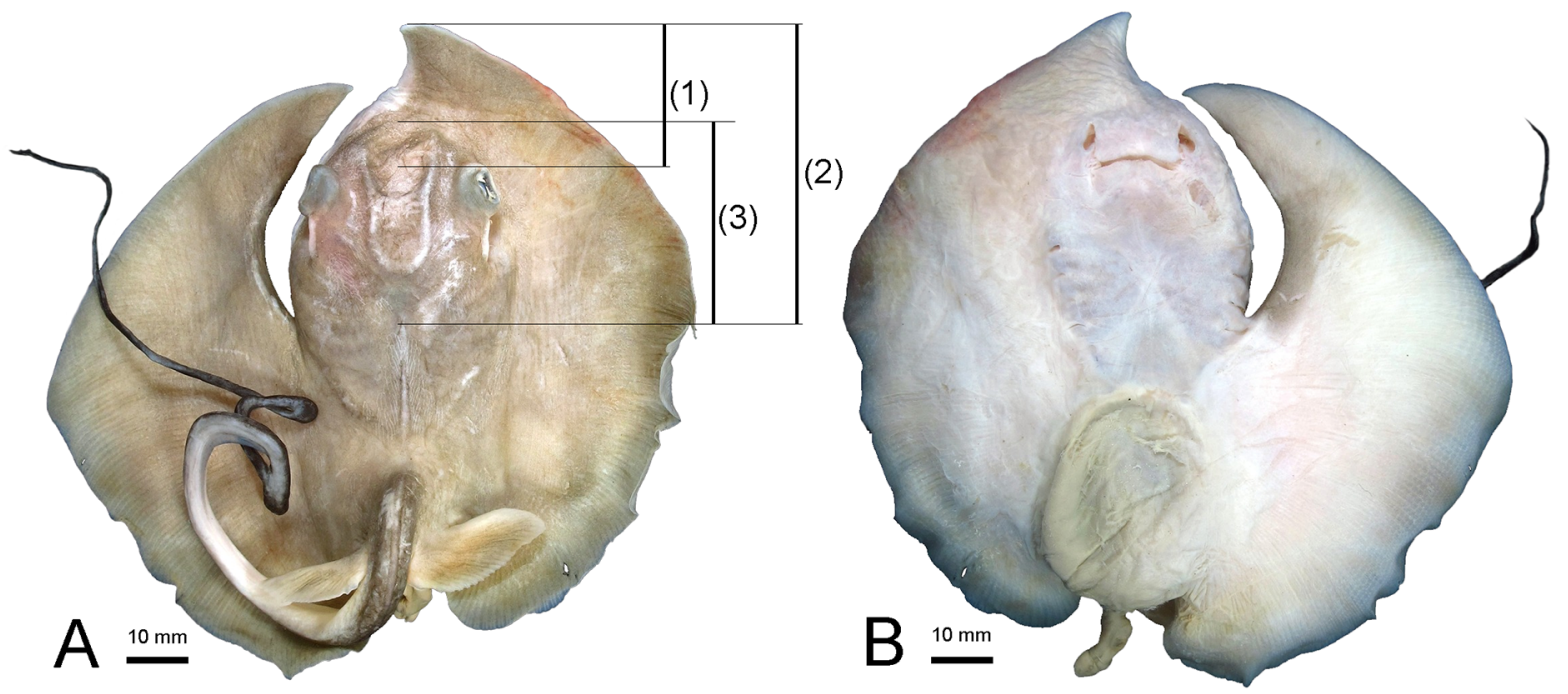

Figure 2. Embryo Hypanus guttatus (Bloch \& Schneider, 1801), collected off the Brazilian Amazon Coast (GEA 3677), disc width $=95.9 \mathrm{~mm}$, (a) dorsal view, (b) ventral view. New measurements depicted by (1) preorbital length, (2) snout to aperture end of the pectoral fin, and (3) anterior margin of cranium to aperture end of the pectoral fin; see material and methods for more details.

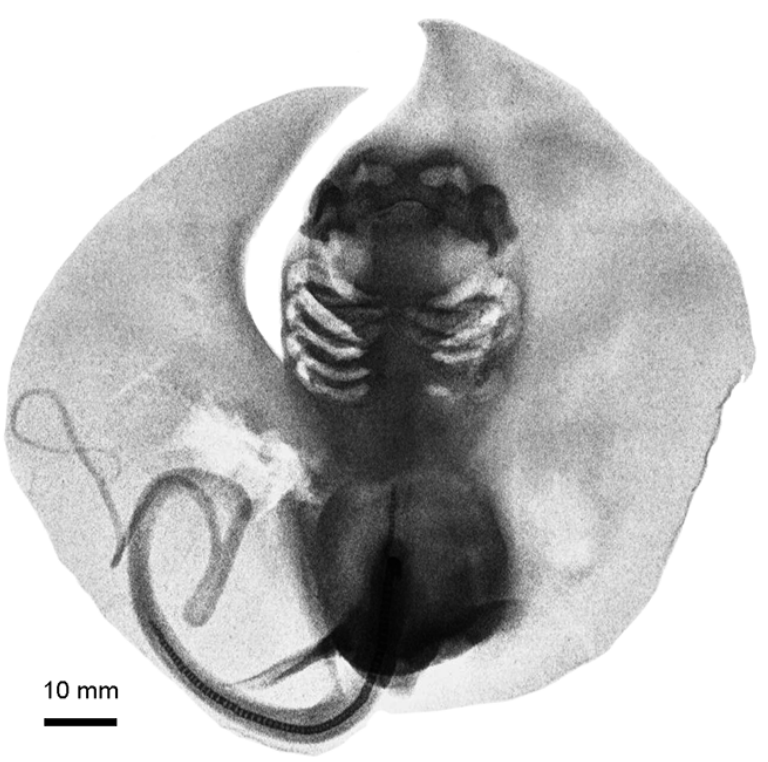

Figure 3. Radiograph of the embryo Hypanus guttatus (Bloch \& Schneider, 1801) (GEA 3677), disc width $=95.9 \mathrm{~mm}$.

potential spatial and/or species-related patterns and, eventually, may help uncovering possible causes.

\section{Acknowledgements}

The specimen was obtained during the "Shrimp NEN" research project (\#445766/2015-8) from the Center for Research and Management of Fishing Resources of Brazil's North Coast of the Brazilian Ministry of the Environment in partnership with the Federal
University of Pará. Thanks to M. Figueiredo (UFRA) for radiograph preparation and to D. McLennan for proofreading the manuscript. This study was financed in part by the Coordenação de Aperfeiçoamento do Pessoal de Nível Superior - Brasil (CAPES) - Finance Code 001 (KS, FSM). MCA receives a National Postdoctoral Fellowship Program (PNPD/CAPES \# 2017-6), JSA is funded by the Conselho Nacional de Desenvolvimento Científico e Tecnológico (CNPQ) and TG receives a productivity grant (CNPq \# 310299/2016-0).

\section{Author Contributions}

Kurt Schmid is the main (first) author of the manuscript and made substantial contribution in the concept and design of the study.

Marcelo Andrade made contribution to data collection, data analysis and interpretation and manuscript preparation.

Fabiola Machado made contribution to data collection, data analysis and interpretation.

Juliana Araujo made contribution to data collection, data analysis and interpretation.

Eglé Corrêa made contribution to data collection.

Tommaso Giarrizzo made substantial contribution in the concept and design of the study, to critical revision, adding intelectual content.

\section{Conflicts of interest}

The author(s) declare(s) that they have no conflict of interest related to the publication of this manuscript.

\section{Data availability}

All data used and analyzed in this study are included in the main text of the manuscript. 


\section{References}

ANDERSON, A.B., CARVALHO-FILHO A., MORAIS R.A., NUNES L.T., QUIMBAYO J.P.A. \& FLOETER S.R. 2015. Brazilian tropical fishes in their southern limit of distribution: checklist of Santa Catarina's rocky reef ichthyofauna, remarks and new records. Check List. 11 (4):1688. DOI: 10.15560/11.4.1688

BIGELOW, H.B. \& SCHROEDER, W.C. 1953. Sharks, sawfishes, guitarfishes, skates and rays. Chimaeroids. In: Tee-Van, J., Breder, C.M., Hildebrand, S.F., Parr, A.E. and Schroeder, W.e. (eds.). Fishes of the Western North Atlantic. Part 2. Sears Foundation for Marine Research, Yale Univ., New Haven: 1-514.

BLANCO-PARRA, M. P. \& NIÑO-TORRES, C. A. 2011. Morphological abnormality in a diamond stingray, Dasyatis dipterura (Jordan \& Gilbert, 1880) (Chondrichthyes: Dasyatidae), from the Gulf of California, Mexico. Cahiers de Biologie Marine 52:357-360.

CARPENTER, K.E. \& NIEM, V.H. 1999. The living marine resources of the Western Central Pacific. Volume 3. Batoid fishes, chimaeras and bony fishes part 1 (Elopidae to Linophrynidae). (FAO species identification guide for fishery purposes. Rome, FAO.)

CERVIGÓN, F. \& ALCALÁ, A. 1999. Los peces marinos de Venezuela. Tiburones y rayas. Fundación Museo del Mar, (Eds.). 230 pp.

ESCOBAR-SÁNCHEZ, O., GALVÁN-MAGAÑA, F., DOWNTOWNHOFFMANN, C. A., CARRERA-FERNÁNDEZ, M., \& ALATORRERAMÍREZ, V. G. 2009. First record of a morphological abnormality in the longtail stingray Dasyatis longa (Myliobatiformes: Dasyatidae) in the Gulf of California, Mexico. Marine Biodiversity Records. 2:1-3. DOI: https:// doi.org/10.1017/S1755267208000304

FROESE, R. \& PAULY, D. 2018. FishBase. World Wide Web electronic publication. Retrieved from http://fishbase.org

GOMES, U.L., SANTOS, H.R.S \& MEDINA, A.E. 1991. Anophthalmia in Dasyatis sayi (LeSueur, 1817) (Myliobatiformes, Dasyatidae). Anais da Academia Brasileira de Ciências. 63(3):307-313.
GOMES, U.L., ROSA, R.S. \& GADIG, O.B.F. 2000. Dasyatis macrophthalma sp. n.: a new species of stingray (Chondrichthyes: Dasyatidae) from the southwestern Atlantic. Copeia. 2000 (2): 510-515. DOI: 10.1643/0045-8511(2000)000[0510:DMSNAN]2.0.CO;2

MANCINI, P.L., CASAS, A.L. \& AMORIM, A.F. 2006. Morphological abnormalities in a blue shark Prionace glauca (Chondrichthyes: Carcharhinidae) foetus from southern Brazil. Journal of Fish Biology. 69:1881-1884. DOI: https://doi.org/10.1111/j.1095-8649.2006.01238.x

LAMILLA, J., PEQUEÑO, G., \& KONG, I. 1995. Dasyatis brevis (Garman, 1880). Second species of Dasyatidae registered for Chile (Chondrichthyes, Myliobatiformes). Estudios Oceanológicos. 14:23-27.

LAST, P.R., WHITE, W., DE CARVALHO, M.R., SÉRET, B., STEHMANN, M. \& Naylor, G. 2016. Rays of the world. Clayton North: CSIRO Publishing.

LAST, P.R., NAYLOR, G.J.P. \& MANJAJI-MATSUMOTO, B.M. 2016. A revised classification of the family Dasyatidae (Chondrichthyes: Myliobatiformes) based on new morphological and molecular insights. Zootaxa. 4139:345-368. DOI: 10.11646/zootaxa.4139.3.2

RAMÍREZ-HERNANDEZ, A., PALACIOS-BARRETO, P., GAITÁN-ESPITIA, J.D., REYES, F. \& RAMIRÉZ, J. 2011. Morphological abnormality in the longnose stingray Dasyatis guttata (Myliobatiformes: Dasyatidae) in the Colombian Caribbean. Cybium: international journal of ichthyology. 35:79-80.

RIBEIRO-PRADO, C.C., ODDONE, M.C., GONZALEZ, M.M.B., AMORIM, A.F. \& CAPAPÉ, C. 2008. Morphological abnormalities in skates and rays (Chodrichthyes) from off southeastern Brazil. Arquivos de Ciências do Mar. 41: 21-28.

ROSA, R.S. \& FURTADO, M. 2004. Dasyatis guttata. The IUCN Red List of Threatened Species 2004: e.T44592A10911036. DOI: 10.2305/IUCN. UK.2004.RLTS.T44592A10911036.en

Received: $11 / 05 / 2019$

Revised: 01/07/2019

Accepted: 02/07/2019

Published online: 29/07/2019 